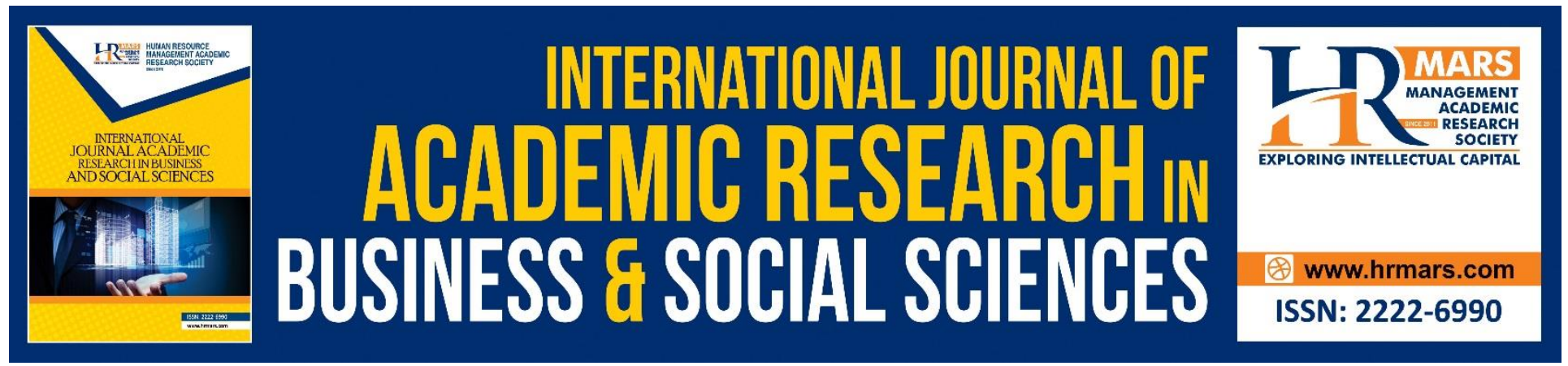

\title{
Stress as a Mediator of Work-Family Conflict and Turnover Intention in Selected Savings and Loans Companies in Ghana
}

Daniel Ofori, Jane Dodoo, Isaac Nyarko Adu, Michael Asiedu Gyensare

To Link this Article: http://dx.doi.org/10.6007/IJARBSS/v8-i9/4654 $\quad$ DOI: $10.6007 / I J A R B S S / v 8-i 9 / 4654$

Received: 12 August 2018, Revised: 04 Sept 2018, Accepted: 29 Sept 2018

Published Online: 15 October 2018

In-Text Citation: (Ofori, Dodoo, Adu, \& Gyensare, 2018)

To Cite this Article: Ofori, D., Dodoo, J., Adu, I. N., \& Gyensare, M. A. (2018). Stress as a Mediator of Work-Family Conflict and Turnover Intention in Selected Savings and Loans Companies in Ghana. International Journal of Academic Research in Business and Social Sciences, 8(9), 770-793.

Copyright: (C) 2018 The Author(s)

Published by Human Resource Management Academic Research Society (www.hrmars.com)

This article is published under the Creative Commons Attribution (CC BY 4.0) license. Anyone may reproduce, distribute, translate and create derivative works of this article (for both commercial and non-commercial purposes), subject to full attribution to the original publication and authors. The full terms of this license may be seen at: http://creativecommons.org/licences/by/4.0/legalcode

Vol. 8, No. 9, September 2018, Pg. 770 - 793

Full Terms \& Conditions of access and use can be found at http://hrmars.com/index.php/pages/detail/publication-ethics 


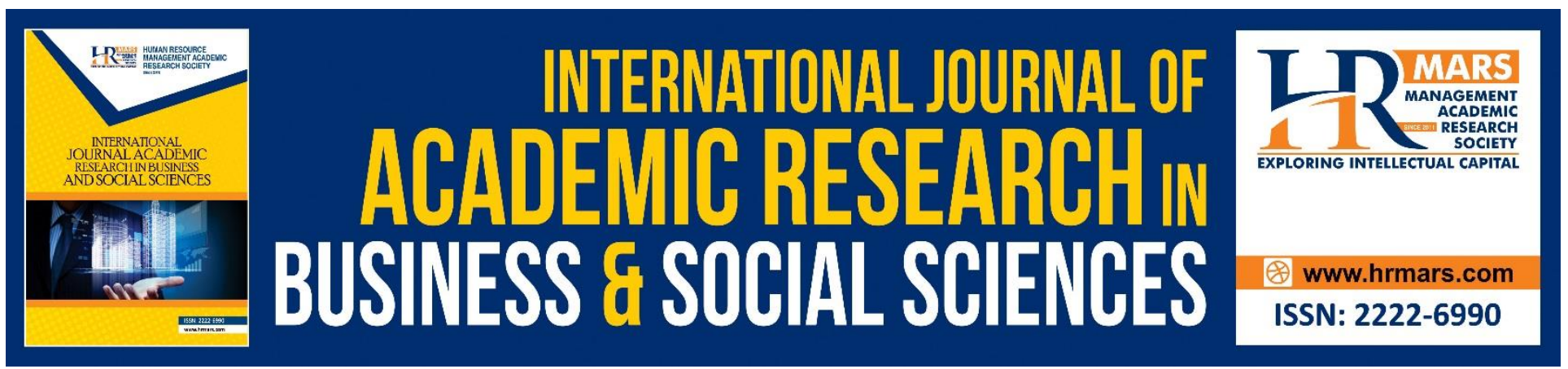

\title{
Stress as a Mediator of Work-Family Conflict and Turnover Intention in Selected Savings and Loans Companies in Ghana
}

\author{
Daniel Ofori ${ }^{1}$, Jane Dodoo ${ }^{2}$, Isaac Nyarko Adu ${ }^{3}$, Michael Asiedu \\ Gyensare ${ }^{3}$ \\ ${ }^{1}$ Department of Organization and Human Resource Management, University of Ghana, Ghana. \\ Email:dofori@ug.edu.gh \\ 2Ebenezer Senior High School, Ghana, Email: janedodoo2002@yahoo.com \\ ${ }^{3}$ Department of Human Resource Management, University of Education, Winneba-Ghana. Email: \\ inadu@uew.edu.gh, magyensare@uew.edu.gh
}

\begin{abstract}
This study examined occupational stress as a mediator of work-family conflict and turnover intention in selected Savings and Loans Companies (SLCS) in Ghana. Descriptive cross-sectional research design was adopted for the study. One hundred and twenty-six (126) respondents from three firms were selected using simple random sampling and purposive sampling techniques. A structured and selfadministered questionnaire was the main data collection instrument. Data was analysed with the help of SPSS whilst the hypotheses were tested through correlation and multiple regression analysis. The study found a significant positive relation among work-to-family conflict, family-to-work conflict and occupational stress. Also, occupational stress had a positive effect on turnover intention. However, work-to-family conflict rather than family-to-work conflict significantly predicted turnover intention. Finally, the relation between work-family conflict and turnover intention was fully mediated by occupational stress. It was recommended among others those work-family interventions such as flexitime, compressed workweek and job sharing should be implemented by management in the Savings and Loans Companies (SLCS) to help lessen the burden that comes with employee turnover.

Keywords: Work-family Conflict, Family-Work Conflict, Stress, Turnover, Savings And Loans

\section{Background of the Study}

Workforce diversity and organizational restructuring have made studying the relation between work and family issues more fascinating in the last two decades. According to Bennett, et. al. (2016), workfamily conflict (WFC) has become a major area of research due to the main challenges confronting
\end{abstract}


INTERNATIONAL JOURNAL OF ACADEMIC RESEARCH IN BUSINESS AND SOCIAL SCIENCES Vol. 8, No. 9, Sept. 2018, E-ISSN: 2222-6990 @ 2018 HRMARS

employees, especially women in balancing work and family responsibilities (Moreno-Jimenez et al. 2009).

In addition, work-family conflict is an important area for practitioners because it has been empirically confirmed to relate to negative work attitudes (Deery, \& Jago, 2015) and turnover intention (Boyar et al., 2005). It is therefore imperative that management of Savings and Loans Companies (SLCs) take keen interest in this emerging labour challenge whose dynamics are subtly becoming complicated. Two separate forms of work-family conflict exist: work-to-family conflict and family-to-work conflict (Hoang, 2009). Work-to-family conflict could be observed as the unfavourable impact of work demands on the fulfilment of family responsibilities whereas family-to-work conflict is the negative effect of family responsibilities on performance in the workplace (Hoang, 2009).

Sonnentag and Fritz (2015) found that long working hours primarily contribute to an increase in workfamily conflict and eventually to psychological distress. Consequently, issues of time and other factors (e.g. working parents, dual career couples) have attracted research attention in work-family conflict, stress and their associated outcomes. Most employees, especially women, move from one institution to the other where they feel they can manage their roles in the office as well as the home (Slaughter, 2015). Hence, Bedu-Addo (2010) opined that work-family conflict cannot be taken for granted given the drastic surge in the involvement of women in the workforce in nearly all employment areas in Ghana like the rest of the world.

Stress is an unpleasant emotional and psychological condition which results from an unfavourable work experience beyond the employee's control (Hart \& Cooper, 2001; Judge\& Colquitt, 2004). According to Spector (2017), occupational stress is the transactional process in which employees' experience of stressors, events or properties of events cause strain among them which eventually leads to certain results at both an individual and organizational level. Basically, stress is a form of unpleasant emotion and has the potential to increase employee turnover (Oreg, et al. 2018). Also, work-related stress and its effects on mental issues are associated with the tendency for an employee to leave his/her job (Braaten, 2000).

When stress is perceived at the work place on a higher degree, employees, especially women are likely to leave the organization. Consistent with this view, some scholars (e.g., Kavanagh, 2005; Orgambídez-Ramos et. al. 2014) have argued that higher stress leads to higher employee turnover intention. An individual's psychological, physical and behavioural responses to stressors arise when the environmental demands exceeds the individual's resources (Blomme, Rheede \& Tromp, 2010). Renowned scholars like Orgambídez-Ramos, (2014) categorise stressors into three: contextual, rolerelated and personal stressors. Nonetheless, Nilsen, et. al. (2016) have also recognised personal, structural organizational, procedural, organizational and role characteristics as other forms of stressors.

Finally, research has shown that conflict occurs between work and family when individuals have to perform multiple roles as worker, spouse and parent (Kelly et. al., 2014). Each of these roles involves time and energy if it is to be carried out satisfactorily. Thus, individuals are sometimes overwhelmed 
INTERNATIONAL JOURNAL OF ACADEMIC RESEARCH IN BUSINESS AND SOCIAL SCIENCES Vol. 8, No. 9, Sept. 2018, E-ISSN: 2222-6990 @ 2018 HRMARS

and experience interference from work-to-family or family-to-work (Lam, Fan, \& Moen, 2015). Advancing this argument, Aslam et al. (2010) observed that work-family conflict attributes greatly to an employee's intention to leave the organization. Against this background, the study sought to examine the mediating effect of stress on the relation between work-family conflict and turnover intention among employees in the Savings and Loans Companies in Ghana.

Although numerous empirical and theoretical researches have been conducted on work-family conflict, stress and turnover intention, these studies have focused on developed countries to the neglect of similar studies in developing countries like Ghana. In addition, these studies (Allen, 2013; Mulki, \& Wilkinson 2017) have examined conflicts between work-to-family and family-to-work as well as family-friendly policies in organizations where work-family culture relates to desirable outcomes for employees with families.

Further, though studies by Shahzad et al. (2011) and Matthews, et al. (2014) have highlighted how work and family role features affect work-family conflict, these studies have failed to examine the mechanism of occupational stress in mediating the effect of work-family conflict on employee turnover intention. In addition, these studies have been conducted with samples from the public sector organizations leaving out similar studies in the private sector, particularly in Savings and Loans Companies (SLCS) in a developing context. .These contextual and geographical gaps in the view of the researcher are worth looking into.

Further, empirical findings from Ghana show that some Ghanaian relationships have collapsed due to partners not spending quality time with each other as a result of the pressures from work (BeduAddo, 2010). Again, the view of the Ghanaian society that women should play a submissive role to men which is seriously threatened by the recent creed for women calling for quality places huge burdens on career women in relationships. Though some have tried to swap one job for the other due to influence of stress and work-family conflict on turnover intention, the challenge still persists. Others have to let go their marriages for their jobs due to their inability to manage the apparent influence of stress and work - family conflict. Even though an interaction between the various life domains has been found to exist, most researchers in the field of job stress limit their attention to activities in the work domain and neglect how work experiences can affect other areas, such as the family domain (Menges, Tussing, Wihler, \& Grant, 2017).

This study therefore seeks to determine the mediating effects of stress on the relationship between work-family conflict and turnover intentions in SLCs in Ghana.

Research carried out previously indicates that when work-family conflict is intensified it leads to higher levels of stress reactions which in turn influence work attitude such as turnover intention (Panatik, et. al., 2012).For instance, in a similar study which examines the relationship between workfamily conflict and turnover intention with mediating effect of stress among four public sector universities in Pakistain it was revealed that a positive relationship exist between work-family conflict and turnover intention, and that stress mediates positively in work-family conflict turnover intention (Khan, et. al, 2014). Also, work -family conflict could generate a negative emotion (e.g. sadness) 
INTERNATIONAL JOURNAL OF ACADEMIC RESEARCH IN BUSINESS AND SOCIAL SCIENCES Vol. 8, No. 9, Sept. 2018, E-ISSN: 2222-6990 @ 2018 HRMARS

which is a symptom of stress (Kim, et. al., 2013). This would thus affect workers feelings such as unhappiness and the absence of job satisfaction. Similarly, in a study conducted by Panatik et al. (2012) on Work-family conflict and work-related attitude: The mediating effects of stress reactions among academician in Malaysia it was realised that work-family conflict is significantly related to stress reaction which eventually mediates the effects of work-family on work related attitude like turnover intention.

In another study, Galea, Houkes, and De Rijk, (2014) posited that there is no one size fit solution to the issue of work life conflict so a variety of strategies, practices and policies should be employed to decrease the work life conflict. In their studies on, 'The Impact of Work Family Conflict on Turnover Intentions: Empirical Evidence from Naeem et al. (2013) established that work family conflicts leads to a maximum stress which eventually makes an employee to redraw from work. Similarly, in a study of work-family conflict, family-work conflict and the contingent effect of self-efficacy of retail sales people in a transitional economy conducted by Chelariu \& Stump (2011) it was discovered that WFC is strongly related to job stress, while FWC is not, and that job stress fully mediates the effect of WFC on turnover intentions. In her study, Esson (2004) asserted that Job stress serves as a mediator between work-family conflict and several other variables. The model proposed in her study suggests that intention to turnover is a distal (indirect) consequence of work-family conflict because of its strong relationships to other variables that are also the results of mediated relationships (Esson 2004). Therefore from the review so far stress could mediate between work-family conflict and other variables like and turnover.

\section{Method}

\section{Research Design}

Descriptive cross-sectional design was chosen as the framework of this study. Descriptive survey is a type of non-experimental research in which the manipulation of variables and randomization of samples are not present (Gyensare \& Asare, 2012; Leedy \& Ormrod, 2010). In this type of research, the investigator approaches the phenomenon as it exists, affecting the direction in which inferences can be made about the study's findings.

\section{Population}

The target population for this study comprised of employees in the SLCs in Ghana. According to statistics by GHASALC (2013) there are 18 registered SLCs under the regulation of the Financial Institutions (Non-Banking) Law in 1993 (PNDCL 328) with about 170 branches in the entire country. The list of the 18 SLCs include: ProCredit, First Allied, Union, Ezi, Advans, Women World Bank Ghana (WWBG), Express, Adehyeman, Beige Capital, Pacific, UniCredit, Multi-Credit (MCSL), $1^{\text {st }}$ National, EBACCION, Midland, Opportunity International, Global Access and Sinapi Aba. However, the accessible population was limited to employees of three SLCs (i.e., Adehyeman, Advans Ghana and Beige Capital). The total number of employees in all three SLCS was approximately 956. The selection of these three SLCs was based on the premise that most of the SLCs contacted were unwilling to participate in the study due to an organizational policy that sanctions them from making company information public. 


\section{Sample and Sampling Technique}

Out of the accessible population of about 950 employees, a sample size of 282 respondents was selected for the study. The study adopted probability sampling techniques for the selection of the respondents. First, proportionate stratified sampling technique was used to categorize the number of respondents into three strata (strata A, B \& C). The stratification variable used was the departments within the company. Next, the researcher employed the random sampling technique to select the participants from the three groups. Thus, each participant had an opportunity to participate in the study during the sampling process. The choice of these techniques were based on Neuman's (2007) assertion that proportional stratified and simple random sampling procedures guarantee proportional representation of the participants as well as equal chance of participants being selected. Thus, this enables the researcher to extrapolate the findings beyond the sample distribution.

\section{Research Instruments}

A self-administered questionnaire was used in the data gathering process. The questionnaire had four parts: demographic characteristics of respondents, work-family conflict, employee turnover intention and stress. First, work-family conflict will be discussed followed by turnover intention and stress respectively.

\section{Work-Family Conflict}

Work-family conflict was assessed using the Work-Family Conflict Scale (WFCS; Netemeyer, Boles \& McMurrian, 1996). The 10-item measure assesses the extent of both work-family conflict and familywork conflict. The subscales for work-family conflict and family-work conflict are parsimonious, using five items each. Responses are anchored on a 7-point Likert type scale where 1 represents strongly disagree and 7 strongly agree. Sample items of the WFC and FWC are "The demands of my work interfere with my home family life" and "The demand of my family or partner interfere with workrelated activities" The coefficient alpha values for both work-family conflict and family-work conflict ranges from .88 to .89 (Allen, et. al. 2013). The coefficient alpha for the WFC and FWC in this study were $\alpha=.868$ and $\alpha=.775$ respectively.

\section{Turnover Intention}

Employee turnover intention was measured using the Intention to Turnover Scale (ITS) by Colarelli (1984). Responses on all 3-items were anchored on a 5 point rating scale ranging from 1 strongly disagree to 5 strongly agree. A sample item of the TIS is, "I frequently think of quitting my job" and "Before long, I will be leaving my present job" the items in the survey represents the future intentions of an employee to stay with his or her current organization or seek employment elsewhere. Shuck (2010) and Gyensare (2013) both reported coefficient alpha's of .81 and .79 respectively. The coefficient alpha for the TIS in the present study was $\alpha=.650$.

\section{Occupational Stress}

Stress was measured by the Occupational Stress Scale (OSS) (Fields, 2002). The 15-item OSS measure consists of five dimensions: responsibility pressure, quality concerns, role conflict, job vs. non-job 
INTERNATIONAL JOURNAL OF ACADEMIC RESEARCH IN BUSINESS AND SOCIAL SCIENCES

Vol. 8, No. 9, Sept. 2018, E-ISSN: 2222-6990 @ 2018 HRMARS

conflict and workload. Employees were asked to rate their responses on a 5-point Likert scale ranging from 0 not at all to 4 nearly all the time. Sample items of the OSS are "I feel I have too much responsibility for the work of others" and "I think that the amount of work I have to do may interfere with how well it gets done" Coefficient alpha values ranges from .59 to .76 for responsibility pressure, and from .56 to .76 for job vs. non-job conflict (Holder \& Vaux, 1998). Alpha for quality concerns, role conflict and workload stress were .72, .70 and.73 respectively (House et al., 1979). The coefficient alpha for the OSS measure in the present study was $\alpha=.864$.

\section{Data Analysis}

Data collected from the survey design was analyzed quantitatively using both descriptive and inferential statistics. The data gathered was first edited to remove errors and then coded. Statistical Product and Service Solutions (SPSS 20.0 version) was used for the entry and analysis of the data. The demographic characteristics of respondents were examined using descriptive statistics such as frequency, percentage, means and standard deviations. Besides, all the constructs were inspected for statistical significance using Pearson's correlation and multiple regression analyses. Finally, all the latent variables were continuous in nature and thus, the hypotheses were tested at the .05 level of significance.

\section{Results and Discussion}

\section{Descriptive Statistics of the Study Variables}

Normality testing could be conducted graphically or quantitatively (Field, 2009). In checking for the normal distribution of the data, kurtosis and skewness index were employed for each variable. Following Kline's (2005) rules of thumb, absolute values of skew index less than 3 and kurtosis index below 10 suggest that the data is normally distributed. The skewness and kurtosis indexes as illustrated in Table 4.2, below reveals that all the constructs were normally distributed. Hence, the assumption of normality was met for the use of parametric statistics for the data analysis (Harrington, 2009). Finally, the reliability coefficients (Cronbach's $\alpha$ ) were computed to establish the internal consistency measure of each construct. All the constructs had satisfactory reliabilities according to Nunnally and Bernstein (1994) who suggested that the coefficient alpha should be greater than or equal to .70 if a set of items can constitute a reliable scale. The alpha values ranged from .70 to .95 as shown in Table 4.2. Finally, as part of the preliminary analysis, the correlation coefficients between the predictor variables ranged from .55 to .59 which were all below the threshold of .80 (Field, 2009; Gaur \& Gaur, 2009; Gujarati, 2004) indicating that multicollinearity was not a problem and thus regression analysis could be employed.

Table 1: Descriptive statistics and reliability indices of study variable

\begin{tabular}{lccccccc}
\hline Variable & Min. & Max. & Mean & SD & Skewness & Kurtosis & Alpha \\
\hline Work-to-family conflict & 1.00 & 5.00 & 3.77 & 0.92 & -.752 & -.379 & .92 \\
Family-to-work conflict & 1.00 & 5.00 & 3.22 & 1.20 & -.061 & -1.297 & .95 \\
Occupational stress & 1.27 & 5.00 & 3.52 & 0.65 & -.247 & -.540 & .88 \\
Turnover intention & 1.00 & 5.00 & 3.17 & 0.80 & -.394 & .642 & .70 \\
\hline
\end{tabular}


Besides the assumptions of normality and multicollinearity, the study also looked at the mean score sand with their corresponding standard deviations for the key variables of the study. From Table 1, it was observed that work-to-family conflict recorded the highest score, with a mean of 3.77. Occupational stress had the next highest mean score of 3.52 out of the total possible score of five followed by family-to-work conflict with a mean score of 3.22. Turnover intention scored the lowest mean value of 3.17. The scores indicate that employees in the SLCs are particularly concerned with the extent to which their work activities affect their family as well as the stress emanating from the work-to-family conflict spillover.

\section{Analysis of Research Objectives}

Cross tabulation analysis of the association between demographic variables and study variables (i.e., work-family conflict, work stress and turnover intention) were examined for meaningful relations using chi-square test. Creswell (2009) stated that inferential statistical procedure such as chi-square help researchers draw conclusions about a population from a sample and provide evidence regarding the generalizability of findings to a broader population. This section however utilized a chi-square analysis to test the null hypothesis $\left(H_{0}\right)$, meaning there is no significant difference between the expected and observed result of a given variable distribution.

\section{Testing of Hypotheses}

The formulated hypotheses were tested using two main parametric statistical tools. The tools included Pearson's Product-Moment Correlation (PPMC) and Multiple Regression Analysis (MRA). In view of the fact that all the items were anchored on a 5 point Likert scale, data transformation was carried out with subscales aggregated together to establish a total composite score for each variable. In addition, a mediated regression analysis was carried out following Baron and Kenny's (1986) way of conducting mediation analysis.

\section{Hypothesis One}

H1a: Work-to-family conflict is positively related to occupational stress among employees in the SLCs in Ghana.

H1b: Family-to-work conflict is positively related to occupational stress among workers in the SLCs in Ghana.

Hypothesis 1 stated that there would be a positive relationship among work-to-family conflict, familyto-work conflict and occupational stress. In order to test this hypothesis at the .05 level of significance, Pearson's product moment correlation coefficient was employed. Table 2 presents the output of the correlation analysis. 
INTERNATIONAL JOURNAL OF ACADEMIC RESEARCH IN BUSINESS AND SOCIAL SCIENCES Vol. 8, No. 9, Sept. 2018, E-ISSN: 2222-6990 @ 2018 HRMARS

Table 2: Pearson's Product-Moment Correlation for W2FC, F2WC, OS and TI

\begin{tabular}{lcccccc}
\hline Variable & VIF & Tolerance & W2FC & F2WC & OS & TI \\
\hline W2FC & 1.74 & .58 & -- & & & \\
F2WC & 1.62 & .62 & $.55^{* * *}$ & -- & & \\
OS & 1.74 & .57 & $.59 * * *$ & $.55^{* *}$ & -- & \\
TI & 1.10 & .91 & $.30 * *$ & $.19 *$ & $.40 * * *$ & -- \\
\hline
\end{tabular}

Note. $N=126 ;{ }^{*} p<.05, * * p<.01,{ }^{* *} p<.001$. W2FC is Work-to-family conflict; F2WC is Family-towork conflict; OS is Occupational stress; $T I$ is Turnover intention; VIF is Variance inflated factor.

Bivariate correlations were utilized to investigate the direct relationships among work-to-family conflict (W2FC), family-to-work conflict (F2WC) and occupational stress (OS). The correlation analysis as shown in Table 2 revealed a significantly positive relationship between W2FC and OS $(r=.59, p<$ $.001)$ as well as between F2WC and OS ( $r=.55, p<.001)$. Hence, both H1a and H1b were supported.

In addition, a positive significant relations were found between W2FC and $\mathrm{TI}(r=.30, p<.01)$ and F2WC and TI ( $r=.19, p<.05)$ among employees in the SLCs in Ghana. Finally, OS was also significantly and positively related to employee $\mathrm{TI}(r=.40, p<.001)$ in the SLCs in Ghana.

The outcome of the correlation analysis suggests that the more W2FC and F2WC employees experienced, the greater the chances they develop more occupational stress and strain and thus increase their intentions to leave the organization. With regards to literature, numerous studies have been conducted among work-family conflict, family-work conflict and occupational stress. For example, researchers like Joseph, Thomas, Antionio, Lourdes and Bless (2007); Greenhaus, Allen, and Spector, (2006) and Poelmans (2001) have hypothesized that work-family conflict is highly related to physical and psychological health issues e.g. stress, strain and that when interaction between the two is unbalanced it generates into stress. Also, Netemeyer et al. (2004) reported a direct relationship between work-family conflict and job stress. This was ascertain as they examined the organizational outcomes of work role and family role variables. They therefore hypothesized that work-family conflict would be directly related to job stress. In another study by Esson (2004) a model was proposed which implies that work-family conflict and family-work conflict have a direct relationship with occupational stress. Hence, both work-family conflict and family-work conflict have a positive relationship with stress.

\section{Hypothesis Two}

H2: Occupational stress will positively predict employee turnover intention in the SLCs in Ghana

Hypothesis 2 examined the extent to which occupational stress predicts the turnover intention of employees in the SLCs in Ghana. Multiple regression analysis was used to examine this hypothesis. The results of the regression analysis are presented in Table 3. 
INTERNATIONAL JOURNAL OF ACADEMIC RESEARCH IN BUSINESS AND SOCIAL SCIENCES Vol. 8, No. 9, Sept. 2018, E-ISSN: 2222-6990 @ 2018 HRMARS

Table 3: Summary of Multiple Regression Analyses for OS, W2FC, F2WC and TI

\begin{tabular}{lllllc}
\hline Model & Variable & F-statistic & $B$ & $\beta$ & $t$-value \\
& Entered & & & & $3.88^{* * *}$ \\
\hline 1 & (Constant) & $24.04^{* * *}$ & 1.42 & & $4.90^{* * *}$ \\
\hline 2 & OS & & 0.50 & 0.40 & $7.43^{* * *}$ \\
& (Constant) & $6.11^{* *}$ & 2.18 & & $2.71^{* *}$ \\
& W2FC & & 0.24 & 0.28 & 0.35 \\
\hline
\end{tabular}

Note. $N=126 ;{ }^{* *} p<.01,{ }^{* *} p<.001 . R^{2}$ for Model $1=.16 ; R^{2}$ for Model $2=.09$. OS is Occupational stress, W2FC is Work-to-family conflict and F2WC is Family-to-work conflict.

Hypothesis 2 examined the direct occupational stress - turnover intention nexus among employees in the SLCs in Ghana. Results of the regression analysis in Table 3 above reveals that occupational stress was a positive and significant predictor of employee turnover intention $(B=.40, t=4.90, p<$ .001) in the SLCs in Ghana. In addition to that, occupational stress contributed significantly to the regression model $1, F(1,124)=24.04, p<.001$ and accounted for $16 \%$ of the variation in employee turnover intention. Thus, hypothesis 2 was supported by the regression analysis. The outcome of the regression analysis, however, shows that the more employees experience stress from their routine work activities, the greater likelihood it is for them to quit their organizations and look out for alternative occupations that are less stressful. For instance, as reviewed in this study, Otis and Pelletier (2005) and Leontaridi and Ward argue that, a significant relationship exist between levels of stress and intention to quit among employees. Also, Braaten (2002) reported that job stress evokes certain psychiatric symptoms which are associated with an employee's tendency to leave the job.

\section{Hypothesis Three}

H3a: Work-to-family conflict will significantly predict turnover intention in the SLCs in Ghana $\mathrm{H} 3 \mathrm{~b}$ : Family-to-work conflict will significantly predict employee turnover intention in the SLCs in Ghana.

Similar to hypothesis 2 , hypotheses $3 \mathrm{a}$ and $3 \mathrm{~b}$ were both examined with multiple regression analysis. The predictor variables, W2FC and F2WC were estimated to significantly affect the criterion variable, which is turnover intention. The results of the analysis as shown in Model 2 of Table 3 found that W2FC $(b=.28, t=2.71, p<.01)$ rather than F2WC $(b=.04, t=.35, p>.05)$ was a significant determinant of employee turnover intention in the SLCs in Ghana. However, the dimensions of workfamily conflict contributed significantly to the regression model $2[F(3,122)=8.48, p<.001]$ and accounted for only $9 \%$ of the variance explained in the criterion variable that is employee turnover intention. As a result, hypothesis $3 a$ rather than $3 b$ was supported by the regression analysis. The result showed that work-to-family conflict was the most significant predictor of employee turnover intention in the SLCs in Ghana. Some relationships have been found to exist among work-family conflict, family-work conflict and employees turnover intention. Work-family conflict rather than family-work conflict had been found to lead to a higher rate of turnover. Example, researchers like Chelariu and Stump (2011) discovered that WFC is strongly related to job stress, while FWC is not. 
Also, Boyar, Maertz, Pearson and Keough, 2003 and Netemeyer et al., 2004 have established a significant relationship between work-family conflict and turnover intention. Moreover, Robert, Arjan and Debbie (2010) reported a positive relationship between work-family conflict and turnover intention among employees of a hospitality industry in a study they conducted. Thus, from the above it may be said that work-family conflict and turnover intention are related.

\section{Mediation Analysis}

According to Kim, Kaye and Wright (2001), a mediator or intervening variable is a mechanism through which an independent variable is able to influence a dependent or criterion variable. Several statistical strategies for testing mediating effect have been recommended in the extant literature which includes path analysis and structural equation modelling. However, this study employed Baron and Kenny's (1986) mediation regressions approach. Baron and Kenny proposed that mediation regression requires three equations to be computed. In the first equation, the mediator variable is regressed on the independent variable, in the second equation the dependent variable is regressed on the independent variable and in the final equation, the dependent variable is simultaneously regressed on both the independent and mediator variables.

In addition, Baron and Kenny (1986) outlined four conditions that must be met for a mediation effect to be ascertained. The four conditions are summarized below:

- First Condition: The independent variable must be significantly related to the mediator variable.

- Second Condition: The independent variable must be significantly related to the dependent variable

- Third Condition: The mediator variable must be significantly related to the dependent variable

- Fourth Condition: The effect of the independent variable must be less in equation three than in equation two.

Baron and Kenny proposed that when all four conditions are met, a mediation effect is present on the relationship between the dependent and independent variables. Further, if the beta coefficient for the independent variable is significant in equation two but not significant in equation three (i.e., when the mediator variable is controlled for) then a full mediation effect is achieved. Partial mediation is present when the beta coefficient for the independent variable in equation three is less than the beta weight in equation two, but is still significant.

\section{Hypothesis Four}

H4a: Occupational stress will mediate the link between work-to-family conflict and turnover intention.

Hypothesis 4a was formulated to ascertain the mediating effect of occupation stress on the link between work-to-family conflict and employee turnover intention. Mediated regression analysis was conducted to examine the efficacy of the formulated hypothesis. The results of the mediated regression analysis is presented in Table 4 below. 
INTERNATIONAL JOURNAL OF ACADEMIC RESEARCH IN BUSINESS AND SOCIAL SCIENCES Vol. 8, No. 9, Sept. 2018, E-ISSN: 2222-6990 @ 2018 HRMARS

Table 4: Mediating effect of OS on the relationship between W2FC and TI.

\begin{tabular}{ccccccc}
\hline Equation & $\begin{array}{l}\text { Dependent } \\
\text { Variable }\end{array}$ & $\begin{array}{l}\text { Independent } \\
\text { Variable }\end{array}$ & $\beta$ & $t$-value & $R^{2}$ & $F$-statistic \\
\hline 1 & OS & W2FC & .558 & $8.23^{* * *}$ & .35 & $67.64^{* * *}$ \\
\hline 2 & $\mathrm{TI}$ & W2FC & .299 & $3.49^{* *}$ & .09 & $12.19^{* *}$ \\
\hline 3 & $\mathrm{TI}$ & W2FC & .092 & .90 & .17 & $12.41^{* * *}$ \\
& & OS & .348 & $3.41^{* *}$ & & \\
\end{tabular}

Note. $N=126 .{ }^{* *} p<.01,{ }^{* * *} p<.001 . W 2 F C$ is Work-to-family conflict, OS is Occupational stress and $T I$ is Turnover intention

Hypothesis 4a predicted that occupational stress (OS) would mediate the positive relationship between work-to-family conflict (W2FC) and turnover intention (TI). Table 4 presents the findings of the three regression equations estimated. In the first equation, OS was regressed on W2FC and their relationship was found to be positive and significant and $35 \%$ of the variance in OS was accounted for solely by W2FC. In equation two however, TI was regressed on W2FC and their relationship also was found to be significant but this time at .01 level of significance. In the final equation, TI was simultaneously regressed on W2FC and OS. The relationship between TI and W2FC was not significant $(B=.092, t=.90, p>.05)$ as expected. However, the relation between $\mathrm{TI}$ and OS was significant $(B=$ $.348, t=3.41, p<.01)$ in equation three. Consequently, since the beta coefficients of the independent variable in equation 3 is less than that of equation 2 as indicated in the fourth condition outlined by Baron and Kenny (1986), it is concluded that OS mediated the relationship between W2FC and TI.

Furthermore, the result was full mediation because the effect of W2FC on $\mathrm{Tl}$ in equation 3 was not significant at .05 level of significance. Finally, this hypothesis examined the degree to which occupational stress mediated the association between work-to-family conflict and employee turnover intention. Results of the mediated regression analysis revealed that occupational stress was a significant and meaningful intervening variable for the link between work-to-family and employee turnover intention. As pertains to studies which examines the mediating effect of stress the following were established; Panatik et al. (2012) concluded in their study that work-family conflict is significantly related to stress reaction which eventually mediates the effects of work-family on work related attitude like turnover intention. Again, in another study by Sarooj and Nazia (2008), they proposed that work life conflict and stress have a significant positive relationship with turnover intention. Furthermore, Khan, Nazir, Kazmi, Khalid, Kiyani and Shahzad (2014) revealed that a positive relationship exist between work-family conflict and turnover intention, and that stress mediates positively in work-family conflict turnover intention in a study conducted in Pakistan. In effect stress has been found to mediate the relationship between work-family conflict and turnover intention.

H4b: Occupational stress will mediate the link between family-to-work conflict and turnover intention.

Similarly, hypothesis $4 b$ was postulated to find out the mediating effect of occupational stress on the link between family-to-work conflict and employee turnover intention. To achieve this purpose, 
INTERNATIONAL JOURNAL OF ACADEMIC RESEARCH IN BUSINESS AND SOCIAL SCIENCES Vol. 8, No. 9, Sept. 2018, E-ISSN: 2222-6990 @ 2018 HRMARS

Baron and Kenny's mediated regression procedure was employed. The outcomes of the mediated regression analysis are illustrated in Table 5.

Table 5: Mediating effect of OS on the relationship between F2WC and TI.

\begin{tabular}{ccccccc}
\hline Equation & $\begin{array}{l}\text { Dependent } \\
\text { Variable }\end{array}$ & $\begin{array}{l}\text { Independent } \\
\text { Variable }\end{array}$ & $\beta$ & $t$-value & $R^{2}$ & $F$-statistic \\
\hline 1 & OS & F2WC & .55 & $7.39^{* * *}$ & .31 & $54.54^{* * *}$ \\
\hline 2 & TI & F2WC & .19 & $2.15^{*}$ & .04 & $4.64^{*}$ \\
\hline 3 & TI & F2WC & -.05 & -.48 & .16 & $12.06^{* * *}$ \\
& & OS & .43 & $4.34^{* * *}$ & &
\end{tabular}

Note. $N=126 .{ }^{*} p<.05,{ }^{* * *} p<.001$. F2WC is Family-to-work conflict, OS is Occupational stress and $T /$ is Turnover intention.

Hypothesis 4b anticipated that occupational stress (OS) would mediate the positive relationship between family-to-work conflict (F2WC) and turnover intention (TI). The outcome of the mediated analysis for the three regression estimates are shown in Table 5 . In the first equation, OS was regressed on F2WC and their relationship was found to be positively significant $(B=.55, t=7.39, p<$ .001 ), with F2WC accounting for $31 \%$ of the variance in OS. Regarding the second equation, TI was regressed on F2WC and their relation was also found to be significant $(B=.19, t=2.15, p<.05)$ with F2WC explaining only $4 \%$ of the variance in TI. In equation three, TI was simultaneously regressed on F2WC and OS. The link between TI and F2WC was not significant ( $\theta=-.05, t=-.48, p>.05)$. However, the relationship between TI and OS was significant $(B=.43, t=4.34, p<.001)$ in the third estimation. However, since the beta weights of the independent variable in equation 3 is less than that of equation 2 as shown in the fourth condition outlined by Baron and Kenny (1986), it was concluded that OS mediated the link between F2WC and TI.

Also, the result was full mediation since the effect of F2WC on $\mathrm{TI}$ in equation 3 was not significant at $5 \%$ level of significance. Similar to $\mathrm{H} 4 \mathrm{a}$, this hypothesis looked at occupational stress as a mediator for the relationship between family-to-work conflict and employee turnover intention and surely, occupational stress found to be a significant and meaningful mediating variable for the relationship between family-to-work conflict and employee turnover intention.

\section{Discussion of Findings}

The study examined the relationship between work-family conflict and employee turnover intention in the SLCs in Ghana. The study further sought to investigate the intervening effect of occupational stress on the link between work-family conflict and turnover intention. Guided by theory and research, the following section discusses the results of each hypothesis tested. Results of this study suggested that there were statistically significant and meaningful relationships to explore among the variables of interest. First, $\mathrm{H} 1 \mathrm{a}$ and $\mathrm{1b}$ is explored followed by $\mathrm{H} 2, \mathrm{H} 3 \mathrm{a}$ and $3 \mathrm{~b}$ as well as $\mathrm{H} 4 \mathrm{a}$ and $4 \mathrm{~b}$. 
INTERNATIONAL JOURNAL OF ACADEMIC RESEARCH IN BUSINESS AND SOCIAL SCIENCES

Vol. 8, No. 9, Sept. 2018, E-ISSN: 2222-6990 (C) 2018 HRMARS

\section{Hypothesis One}

The first hypothesis stated that there would be a positive relationship between work-to-family conflict, family-to-work conflict and occupational stress. Results of the correlational analysis indicated there was a significant positive relation between work-to-family conflict, family-to-work conflict and occupational stress. Findings show support for $\mathrm{H} 1 \mathrm{a}$ and $\mathrm{H} 1 \mathrm{~b}$ and thus, the null hypothesis was rejected.

Employees who faced a high degree of work-to-family conflict and or family-to-work conflict (F2WC) were more likely to experience stressed out with their daily activities in the workplace. The findings are in accordance with previous studies that link work-family conflict to occupational stress (Rusli, Edimansyah \& Naing, 2006). For instance, Lam, Fan and Moen, (2015) argued that time spent on activities within the family role such as providing care for children cannot be devoted to activities within the work role. Hence, the requirements of different roles may compete for a person's limited time resources and the time pressures associated with participation in one role may make it physically impossible to comply with the demands from another role (Alavi et. al., 2013). Essentially, time and energy spent on family-related activities cannot be spent on work-related activities, thereby creating family-work conflict for the individual who eventually begins to experience stress and strain in the organization.

Advancing an argument from the border theory, Badu-Addo (2010) opined that employees with higher status are more likely to experience work-to-family conflict and or family-to-work conflict on a larger scale. This is because higher status increases flexibility and permeability and higher permeability indicates that work-related dimensions are able to easily transcend the home domain (Clark, 2000). Consequently, the potential interference emanating from higher permeability will nevertheless result in higher stress among employees in the work scenario.

In addition, work-family conflict is highly related to physical and psychological health-related issues such as stress and strain (Joseph et al., 2007; Greenhaus, et al., 2006; Poelmans, 2001). Hence, when the interaction between work and family demands is unbalance, it generates into stress (Rode \& Near, 2005). Similarly, Joseph et al. (2007) found that a high level of work-to-family conflict (W2FC) and family-to-work conflict (F2WC) was found to reduce workers health which in turn produces depression and anxiety in them. Consequently, employees reporting high levels of W2FC and or F2WC are more likely to be stressed out and would definitely seek for other avenues that accommodates their dual roles to lessen this inter-role conflict.

\section{Hypothesis Two}

The second hypothesis stated that occupational stress would have a positive effect on employee turnover intention. Results from the multiple regression analysis indicated that occupational stress had a significant positive effect on employee turnover intention. Results of the multiple regression analysis showed support for $\mathrm{H} 2$ and thus, the null hypothesis was rejected. 
Employees who reported high levels of occupational stress were more likely to find alternative jobs that will better accommodate them and reduce their stress and strain conditions. This finding is in agreement with previous studies (Bowling, Beehr \& Grebner, 2012; Leontaridi \& Ward, 2002) on relationship between stress and turnover intention. In an empirical study, Zhang and Lee (2010) reported that stress was experienced directly in the work environment and was created as a result of diverse stressors that existed. Furthermore, research has shown that stress arising from the work environment has a significant impact on employees' job satisfaction (and eventually their turnover intention (Leontaridi \& Ward, 2002). Finally, other studies (Williams, 2003; Layne et al., 2001; Shahzad et al., 2011) have also shown that work stress is positively related to an employees' intention to leave the organization. From the above discussion, it is plausible to conclude that higher stress leads to higher employee turnover intentions. Hence, employees who experience high levels of stress are more likely to look for alternative jobs and thus have a higher tendency of leaving their organizations.

\section{Hypothesis Three}

The third hypothesis stated that work-to-family conflict and family-to-work conflict would significantly predict employee turnover intention in the SLCs in Ghana. Results from the multiple regression analysis presented evidence that supported only the relationship between work-to-family conflict and employee turnover intention and not the linkage between family-to-work conflict and turnover intention. Thus, results show partial support for $\mathrm{H} 3$.

Unlike family-to-work conflict (F2WC), support was found for the significant positive effect of workto-family conflict (W2FC) on turnover intention. As a result, employees reporting high levels of W2FC will look for alternative employment to alleviate this inter-role conflict as alternative employment may provide better work circumstances that better accommodate their family-related needs. Several empirical research (Aslam et al., 2011; Bashir \& Ramey, 2008; Morrell et al., 2004) support the findings of this study. For example, researchers (Yu, 2008; Valcour \& Batt, 2003) have proposed that friendly work life policies and programmes are appropriate for lessening employee turnover intention in the work scenario. From this perspective, Hom and Kinicki (2001) stated that organizations today are on the move to develop work life policies and programmes targeted at reducing employee turnover intention.

Findings from this study are however inconsistent with some research findings in the extant literature. For instance, in an empirical study conducted in Canada, Riley (2006) found no significant relationship between work life conflict and turnover intention. Similarly, Aslam, Shumaila, Azhar and Sadaqa (2011) studied the relationship between W2FC and F2WC and turnover intention of employees in three public and private sector organizations in Pakistan. Using evidence from a primary data, Aslam and colleagues found a positive but insignificant relationship between W2FC, F2WC and turnover intention of employees. Thus, the discussion so far lends support to the insignificant relationship found between F2WC and turnover intention as reported in this study.

From the foregoing discussion, it is worth arguing that conflict arising from work and family domains are more likely to initiate work-related attitudes such as dissatisfaction, lassitude, lethargy and 
INTERNATIONAL JOURNAL OF ACADEMIC RESEARCH IN BUSINESS AND SOCIAL SCIENCES Vol. 8, No. 9, Sept. 2018, E-ISSN: 2222-6990 @ 2018 HRMARS

intention to leave the organization. It is therefore imperative that organizations institute work life policies and programmes such as flexible working and telecommuting to guide and guard against the tendency of employees leaving the organization. This policies and programmes will help lessen the burden that comes with employee turnover in the SLCs in Ghana.

\section{Hypothesis Four}

The fourth hypothesis stated that occupational stress will mediate the relationship between workto-family conflict (W2FC) and family-to-work conflict (F2WC), and turnover intention. Results from the mediated regression analysis presented evidence that occupational stress fully mediated the effect of W2FC and F2WC (Aslam et al., 2011) and employee turnover intention (Lee, et. al., 2016).

The findings of this study are consistent with the spillover theory (Shaw, 2014). The theory posits that positive spillover occurs when the stimulation, satisfaction, happiness and energy an employee has at the workplace crossover into a positive or healthy emotions at home. Contrariwise, a negative spillover occurs when the problems, conflicts as well as energy at the workplace causes stress and strain and eventually preoccupies the employee which makes the participation in the family domain ineffective (Shaw, 2014). Thus, negative spillover encountered the workplace results in stress and stress which eventually leads to intention to leave. Similarly, the findings of this study agrees with Pearlin et al.'s (1981) sociological theory which postulates that the social positions occupied by employees in the social structure often exposes them to stressors (i.e., work-family conflict) which eventually results in stress-related outcomes (i.e., turnover intention). In a later study, Ritter, et. al., (2016) stated that role stress is a kind of stressor that arises from within an individual's role-set which provides stress theory's key link between macro level influence and individual outcomes like turnover intention.

Furthermore, the full mediating effect of occupational stress on the relationship between workfamily conflict and turnover intention is consistent with some empirical findings in the extant literature. For instance, previous empirical studies (Grandy \& Cropanzano, 1999; Panatik, Badri, Rajab \& Yusof, 2012) have shown that when work-family conflict is intensified, it results into higher levels of stress reactions which in turn influence employees work attitudes such as turnover intention. Similarly, Panatik et al. (2012) in an empirical study on work-family conflict, stress reactions and workrelated attitude among academics in Malaysia reported that work-family conflict significantly predicted stress reactions which also mediated the effects of work-to-family conflict and family-towork conflict on work related attitude. In consequence, work-family conflict could result in negative emotion such as exhaustion and or restlessness which is a symptom of stress (Greenhaus, Allen \& Spector, 2006) and stress eventually will force an employee to look for alternative employment avenues that provides better working conditions which invariably will increase the tendency of employee turnover intention in the SLCs in Ghana.

\section{Conclusions of the Study}

Based on the key findings outlined, the following conclusions were drawn. At the outset, the study recorded a positive and significant relations among work-to-family conflict, family-to-work conflict 
INTERNATIONAL JOURNAL OF ACADEMIC RESEARCH IN BUSINESS AND SOCIAL SCIENCES Vol. 8, No. 9, Sept. 2018, E-ISSN: 2222-6990 @ 2018 HRMARS

and occupational stress. Thus, the more employees experience work-to-family conflict and family-towork conflict, the more likely they are to develop more stress and strain arising from their occupation.

Additionally, the study revealed that occupational stress had a significant positive influence on employee turnover intention in the SLCs in Ghana. Based on this finding, it was concluded that the more employees experience stress from their routine work activities, the greater likelihood it is for them to quit the organization and look out for alternative occupations elsewhere or in the same nonbank financial institution (NBFI) that are less stressful.

Further, the study revealed that work-to-family conflict rather than family-to-work conflict was a meaningful contributing factor to employee turnover intention. Work-to-family conflict was therefore found to be the most significant precursor of employee turnover intention in the SLCs in Ghana. As result, the more conflict from work spillover to the employee's family domain, the likelihood it is for him or her to take unscheduled absences and then intend to leave finally.

Finally, the multiple regression analyses revealed that occupational stress fully mediated the proposed relationship between work-to-family conflict, family-to-work conflict and turnover intention of employees in the SLCs in Ghana. The indirect relationship between the dimensions of work-family conflict and turnover intention was meaningful indicating a full mediation analysis for the hypothesized mediation paths. Thus, employees who experienced the spillover and crossover effects of work-to-family conflict and family-to-work conflict were more likely to intend to leave their current organizations.

\section{Recommendations}

Since workplace stress was found to be a significant determinant of employee turnover intention in the SLCS in Ghana, it is recommended that the human resource department in the SLCS should redesign jobs to make them more interesting and challenging as well as stress free. This is because if employees enjoy their work and find it valuable, then they may potentially work even harder than they usually do and eventually decide to stay with the organization even longer than expected. Also, since tension that emanates from work impact on satisfaction and commitment which in turn influences turnover intention, it behoves on human resource managers to implement policies and programmes that seeks to reduce the tension and thus minimizes the intention of employees to turnover.

It is recommended that organizations should provide appropriate support to employees who experience work-to-family to discourage them from taking informal absence and intending to leave. Flexible work interventions such as flexitime, compressed workweek and job sharing should be implemented by management in the SLCs to help lessen employee turnover. In addition, interventions such as child care assistance and family friendly cultures through supportive supervisors and co-workers should be effected to curb the consequence of employee experiencing work-tofamily conflict. Thus, when these interventions are put in place, it is more likely to reduce employee turnover tendencies in the SLCs in Ghana. 
Finally, the study found that the indirect path from work-to-family conflict and family-to-work conflict to turnover intention was fully mediated by occupational stress. Based on this finding, it is recommended that organizations need to develop compatible human resource practices to manage dual career responsibilities of employees. In addition, when work and family demands are balanced and conflict from one domain to the other is minimized, employees become less stressed and demonstrate a more positive attitude towards their jobs and a greater commitment to the organization in which they work. This in turn, results in lowering their turnover intentions. Besides, the SLCs should create a work environment that is family-friendly and characterized by flexible work schedule for workers with special family demands. Thus, when employees benefit from a family friendly and thus become less stress, they would intend to stay longer with the organization and ultimately demonstrates high levels of satisfaction and commitment.

\section{Limitations and Directions for Further Research}

The findings of this study have revealed certain limitations and possible future research directions. To begin with, the conceptual framework and hypotheses generated for the study can be expanded to incorporate potential moderators such as family care services and benefits, flexible working conditions and professional support in the SLCs in Ghana. Furthermore, future research could look at the mediating role of other potential variables such as affective reactions and affective commitment in the relationship between work-family conflict and employee turnover intention in the SLCs in Ghana. Thus, future research could replicate the study by considering the mediating effect of affective reactions and affective commitment at the individual, group and organizational level analysis. Finally, the study was limited to employees in the SLCs in Greater Accra region. It is possible that the phenomenon under study may differ between employees in other regions. Besides, the SLCS is just a fraction of the non-bank financial institutions (NBFIs) in Ghana. Therefore, future research in other contexts is needed to test the robustness of the study findings.

\section{References}

Alavi Arjmand, N., Kashaninia, Z., Hosseini, M. A., \& Rezasoltani, P. (2013). Effect of stress management on job stress and work-family conflict among nurses. Journal of hayat, 18(4), 81-91.

Allen, T. D., Johnson, R. C., Kiburz, K. M., \& Shockley, K. M. (2013). Work-family conflict and flexible work arrangements: Deconstructing flexibility. Personnel Psychology, 66(2), 345-376.

Aslam, R., Shumaila,S., Azhar M. \& Sadaqat, S. (2011). Work-Family Conflicts: Relationship between Work-Life Conflict and Employee Retention - A Comparative Study of Public and Private Sector Employees. Interdisciplinary Journal of Research in Business, 1(2), 18-29.

Babbie, E.R. (1973). Survey research methods. Belmont, CA: Wadsworth.

Baron, R.M. \& Kenny, D.A. (1986). The moderator-mediator variable distinction in social psychological research: Conceptual, strategic, and statistical considerations. Journal of Personality and Social Psychology, 51(6), 11731182.

Bedu-Addo, K.A.P. (2010). Work-family interference among Ghanaian women in higher status occupations. Unpublished doctoral dissertation, University of Nottingham, Nottingham. 
INTERNATIONAL JOURNAL OF ACADEMIC RESEARCH IN BUSINESS AND SOCIAL SCIENCES

Vol. 8, No. 9, Sept. 2018, E-ISSN: 2222-6990 @ 2018 HRMARS

Behson, S.J. (2002). Coping with family-to-work-conflict: The role of informal work accommodations to family. Journal of Occupational Health Psychology, 7, 324-341.

Bennett, M., Beehr, T. A., Ivanitskaya, L. V., \& Cooper, A. (2016). Work-Family Conflict: Differences across Generations and Life Cycle Stages. In Academy of Management Proceedings (Vol. 2016, No. 1, p. 17233). Academy of Management.

Berkman, L. F., Liu, S. Y., Hammer, L., Moen, P., Klein, L. C., Kelly, E., \& Buxton, O. M. (2015). Workfamily conflict, cardiometabolic risk, and sleep duration in nursing employees. Journal of occupational health psychology, 20(4), 420-433.

Blomme, J.R., Rheede, V.A. \& Tromp, M.D (2010). Work-family conflict as a cause for turnover intentions in the hospitality industry. Tourism and Hospitality Research, 10(4), 269-285.

Bowling, N.A., Beehr, T.A. \& Grebner, S. (2012). Combating stress in organizations. International Review of Industrial and Organizational Psychology, 27, 66-87.

Boyar, S. L., Maertz, C. P., Pearson, A. W., \& Keough, S. (2003). Work-family conflict: a model of linkages between work and family domain variables and turnover intentions. Journal of Managerial Issues, 15, 175-192.

Boyar, S.L., Maertz, C.P. Jr \& Pearson, A. (2005). The effects of work-family conflict and family-work conflict on non-attendance behaviours. Journal of Business Research, 58, 919-925.

Braaten, D.J. (2000). Occupational stress in mental health counselors. A master thesis. University of Wisconsin-Stout, Menomonie, Wisconsin.

Burch, T. C. (2015). The Static and Dynamic Impact of Couple-Level Work-Family Conflict on IntraCouple Job Change, Couple Separation and Family Expansion (Doctoral dissertation).

Chelariu, C.,\& Stump, R. (2011) "A study of work-family conflict, family-work conflict and the contingent effect of self-efficacy of retail sales people in a transitional economy". European Journal of Marketing, 45 (11/12) 1660 - 1679.

Cho, D.H \& Son, J.M. (2012).Job Embeddedness and Turnover Intentions: An Empirical Investigation of Construction IT Industries. International Journal of Advance Science and Technology.40

Colarelli, S.M. (1984). Methods of communication and mediating processes in realistic previews. Journal of Applied Psychology, 69, 633-642.

Cooper, C. L., \& Marshall, J. (2013). Occupational sources of stress: A review of the literature relating to coronary heart disease and mental ill health. In From Stress to Wellbeing Volume 1 (pp. 3-23). Palgrave Macmillan UK.

Crain, T. L., Hammer, L. B., Bodner, T., Kossek, E. E., Moen, P., Lilienthal, R., \& Buxton, O. M. (2014). Work-family conflict, family-supportive supervisor behaviors (FSSB), and sleep outcomes. Journal of occupational health psychology, 19(2), 155.

Creswell, J.W. (2009). Research design: Qualitative, quantitative and mixed methods approaches ( $3^{\text {rd }}$ ed.). London: Sage Publications, Inc.

Duxbury, L., \& Higgins, C. (2001). Work-life balance in the new millennium: Where are we? Where do we need to go? Ottawa: Canadian Policy Research Networks. 12 http://www.cprn.org

Eby, L. T., Casper, W. J., Lockwood, A., Bordeaux C., \& Brinkley, A. (2005). Work and family research in IO/OB: Content analysis and review of the literature (1980-2002).Journal of Vocational Behavior,66, $124-197$. 
INTERNATIONAL JOURNAL OF ACADEMIC RESEARCH IN BUSINESS AND SOCIAL SCIENCES Vol. 8, No. 9, Sept. 2018, E-ISSN: 2222-6990 @ 2018 HRMARS

Eddleston, K., Sieger, P., \& Bernhard, F. (2015, January). Crisis Coming Home? Firm Performance During the Economic Crisis and Managers' Work-Family Conflict. In Academy of Management Proceedings (Vol. 2015, No. 1, p. 14542). Academy of Management.

Esson, L. P. (2004). Consequences of work-family conflict: testing a new model of work related, nonwork related and stress-related outcomes. A master thesis, Virginia Polytechnic Institute and State University. Blacksburg, Virginia.

Fellows, K. J., Chiu, H. Y., Hill, E. J., \& Hawkins, A. J. (2016). Work-Family Conflict and Couple Relationship Quality: A Meta-analytic Study. Journal of Family and Economic Issues, 37(4), 509-518.

Field, A. (2009). Discovering statistics using SPSS ( $3^{\text {rd }}$ ed.). London: Sage Publications Ltd.

Fiksenbaum, L. M. (2014). Supportive work-family environments: implications for work-family conflict and well-being. The International Journal of Human Resource Management, 25(5), 653-672.

Frone, M. R. (2003). Work-family balance. In J. C. Quick \& L. E. Tetrick (Eds.), Handbook of occupational health psychology (pp. 143-162). Washington, DC: American Psychological Association

Frone, M. R., Yardley, J. K., \& Markel, K. S. (1997). Developing and testing an integrative model of the work-family interface. Journal of Vocational Behaviour, 50, 145-167.

Galea, C., Houkes, I., \& De Rijk, A. (2014). An insider's point of view: how a system of flexible working hours helps employees to strike a proper balance between work and personal life. The International Journal of Human Resource Management, 25(8), 1090-1111

Gaur, A.S. \& Gaur, S.S. (2009). Statistical methods for practice and research: A guide data analysis using SPSS ( $2^{\text {nd }}$ ed.). New Delhi: Sage Publications.

GHASALC (2012). Database on microfinance institutions of RAFiP capacity building fund (CBF). Achimota: GHASALC.

Ghislieri, C., Gatti, P., Molino, M., \& Cortese, C. G. (2016). Work-family conflict and enrichment in nurses: between job demands, perceived organisational support and work-family backlash. Journal of Nursing Management.

Greenhaus, J. H., Allen, T. D., \& Spector, P. E. (2006). Health consequences of work-family conflict: The dark side of the work-family interface. In Employee health, coping and methodologies (pp. 61-98). Emerald Group Publishing Limited.

Greenhaus, J. H., Parasuraman, S. \& Collins, K. M. (2001), “Career involvement and family involvement as moderators of relationships between work-family conflict and withdrawal from a profession", Journal of Occupational Health Psychology, 6, 91-100.

Gujarati, D.N. (2004). Basic econometrics (4 $4^{\text {th }}$ ed.). New Delhi: McGraw-Hill Companies.

Gyensare, M.A. \& Asare, J-A (2012). Relationship between human resource (HR) practices and perceived performance of psychiatry nurses in Ghana. African Journal of Business Management, 6(6), 2137-2142.

Hair, J.F., Black, W.C., Babin, B.J., \& Anderson, R.E. (2010). Multivariate Data Analysis. Seventh Edition. Prentice Hall, Upper Saddle River, New Jersey 
INTERNATIONAL JOURNAL OF ACADEMIC RESEARCH IN BUSINESS AND SOCIAL SCIENCES

Vol. 8, No. 9, Sept. 2018, E-ISSN: 2222-6990 @ 2018 HRMARS

Hardy, A., McDonald, J., Guijt, R., Leane, E., Martin, A., James, A., \& Green, B. (2016). Academic parenting: work-family conflict and strategies across child age, disciplines and career level. Studies in Higher Education, 1-19.

Harrington, D. (2009). Confirmatory factor analysis. Oxford: Oxford University Press.

Higgins, C., Duxbury, L., \& Johnson, K. L. (2000). Part-time work for women: Does it

Higgins, D.C., Duxbury, D.L., \& Lyons, S. (2007). Reducing Work-Life Conflict: What Works? What Doesn't? Executive Summary.

Hoang, T.H.L. (2009). Work-life balance: The challenge of female entrepreneurs in Vietnam. Unpublished master's thesis, School of Sustainable Development of Society and Technology, Malardalen University, Malardalen.

Holder, J. C., \& Vaux, A. (1998). African American professionals: Coping with occupational stress in predominantly White work environments. Journal of Vocational Behaviour, 53(3), 315-333.

House, J.S., McMichael, A.J., Wells, J.A., Kaplan, B.H. \& Landerman, R.L. (1979). Occupational stress and health among factory workers. Journal of Health and Social Behaviour, 20, 139-160.

Hsu, Y.R. (2011), "Work-family conflict and job satisfaction in stressful working environments: the moderating roles of perceived supervisor support and internal locus of control", International Journal of Manpower, 23, (2) 233-248.

Kazmi, R., Amjad, S., \& Khan, D. (2008). Occupational Stress and its effect on Job Performance: A case study of medical house officers of district Abbotabad. Journal of Ayub Medical College, 20(3), 135-139.

Kelly, E. L., Moen, P., Oakes, J. M., Fan, W., Okechukwu, C., Davis, K. D., ... \& Mierzwa, F. (2014). Changing work and work-family conflict: Evidence from the work, family, and health network. American Sociological Review, 79(3), 485-516.

Khan, R. M.,Kazmi S.,Kazmi S., Khalid, A.,Kiyani,M.T.,\& Shahzad A.(2014). Work-Family Conflict and Turnover Intentions: Mediating Effect of Stress. International Journal of Humanities and Social Science 45(1)92-97.

Kim, J-S., Kaye, J. \& Wright, L.K. (2001). Moderating and mediating effects in causal models. Issues in Mental Health Nursing, 22, 63-75.

Kim, M. G., Kim, K. S., Ryoo, J. H., \& Yoo, S. W. (2013). Relationship between occupational stress and work-related musculoskeletal disorders in Korean male firefighters. Annals of occupational and environmental medicine, 25(1), 9.

Kline, R.B. (2005). Principles and practice of structural equation modelling (2 ${ }^{\text {nd }}$ ed.). New York: Guildford.

Kopelman, R. E., Greenhaus, J. H., \& Connolly, T. F. (1983). A model of work, family and inter role conflict: A construct validation study. Organizational Behaviour and Human Performance, 32,198-215.

Lam, J., Fan, W., \& Moen, P. (2015). Bringing home the bacon: does job insecurity predict work-family conflict among US workers?. In Population Association of America 2015 Annual Meeting. Population Association of America.

Lee, B. K., Seo, D. K., Lee, J. T., Lee, A. R., Jeon, H. N., \& Han, D. U. (2016). Impact of work environment and work-related stress on turnover intention in physical therapists. Journal of Physical Therapy Science, 28(8), 2358-2361. 
INTERNATIONAL JOURNAL OF ACADEMIC RESEARCH IN BUSINESS AND SOCIAL SCIENCES

Vol. 8, No. 9, Sept. 2018, E-ISSN: 2222-6990 @ 2018 HRMARS

Leedy, P. D. (1985). Practical research: Planning and design ( $3^{\text {rd }}$ ed.). New York: Macmillan.

Leedy, P.D. \& Ormrod, J.E. (2010). Practical research: Planning and design ( $9^{\text {th }}$ ed.). Upper Saddle River, NJ: Pearson Education Inc.

Ling, X. (2009) View on Work-family Linkage and Work-family Conflict Model. International Journal of Business and Management, 4(12).229-231

Lo, S. (2003). Perceptions of work-family conflict among married female professionals in Hong Kong. Personnel Review, 32(3), 376-390.

Marino, M., Killerby, M., Lee, S., Klein, L. C., Moen, P., Olson, R.,. \& Buxton, O. M. (2016). The effects of a cluster randomized controlled workplace intervention on sleep and work-family conflict outcomes in an extended care setting. Sleep Health, 2(4), 297-308.

Matthews, R. A., Wayne, J. H., \& Ford, M. T. (2014). A work-family conflict/subjective well-being process model: A test of competing theories of longitudinal effects. Journal of Applied Psychology, 99(6), 1173-1187.

Menges, J. I., Tussing, D. V., Wihler, A., \& Grant, A. M. (2017). When job performance is all relative: how family motivation energizes effort and compensates for intrinsic motivation. Academy of Management Journal, 60(2), 695-719.

Miller, R.L., \& Brewer, J.D. (eds) (2003). The A-Z of social research. London: Sage.

Mina B., Shiva M. E., Melika S., (2012) "Work-family conflict and its antecedents among Iranian operating room personnel", Management Research Review .35(10) 958 - 973.

Moen, P., Kaduk, A., Kossek, E. E., Hammer, L., Buxton, O. M., O’Donnell, E., \& Casper, L. (2015). Is work-family conflict a multilevel stressor linking job conditions to mental health? Evidence from the Work, Family and Health Network. In Work and Family in the New Economy (pp. 177-217). Emerald Group Publishing Limited.

Moreno-Jimenez, B., Mayo, M., Sanz-Vergel, A.I., Geurts, S., Rodriguez-Munoz, A. \& Garrosa, E. (2009). Effects of work-family conflict on employees' wellbeing: The moderating role of recovery strategies. Journal of Occupational Health Psychology, 14(4), 427-440.

Netemeyer, R. G., Brashear-Alejandro, T., \& Boles, J.S. (2004). A cross-national model of job related outcomes of work-role and family role variables: A retail sales context. Journal of the Academy of Marketing Science, 32, 49-60.

Netemeyer, R.G., Boles, J.S. \& McMurrian, R. (1996). Development and validation of work-family conflict and family-work conflict scales. Journal of Applied Psychology, 81(4), 400-410.

Neuman, W.L. (2007). Basics of social research: Qualitative and quantitative approaches (2 ${ }^{\text {nd }}$ ed.). Boston: Allyn and Bacon. Naeem A., Rabia I., Maqsood A., Zahid H., and Atif K., (2013). The Impact of Work

Neuman, W.L. (2007). Basics of Social Research: Qualitative and Quantitative Approaches, 2nd ed., Pearson Education, Inc., Boston, MA.

Nilsen, W., Skipstein, A., \& Demerouti, E. (2016). Adverse trajectories of mental health problems predict subsequent burnout and work-family conflict-a longitudinal study of employed women with children followed over 18 years. BMC psychiatry, 16(1), 384.

Non, A. L., Rimm, E. B., Kawachi, I., Rewak, M. A., \& Kubzansky, L. D. (2014). The effects of stress at work and at home on inflammation and endothelial dysfunction. PloS one, 9(4), e94474. 
INTERNATIONAL JOURNAL OF ACADEMIC RESEARCH IN BUSINESS AND SOCIAL SCIENCES

Vol. 8, No. 9, Sept. 2018, E-ISSN: 2222-6990 @ 2018 HRMARS

Noor, N.M. (2003). Work- and family-related variables, work-family conflict and women's well-being: some observations. Community, Work and Family, 6(3) 1469-3615.

Nunnally, J.C. \& Bernstein, I.H. (1994). Psychometric theory (3 ${ }^{\text {rd }}$ ed.). New York: McGraw-Hill, Inc.

Orgambídez-Ramos, A., Borrego-Alés, Y., \& Mendoza-Sierra, I. (2014). Role stress and work engagement as antecedents of job satisfaction in Spanish workers. Journal of Industrial Engineering and Management, 7(1), 360-372.

Panatik, B. A.S., Badri, Z. B. K.S., Rajab, B., A. \& Yusof, M., B.,R.,(2012). Work-family conflict and workrelated attitude: The mediating effects of stress reactions. International Journal of Social Sciences and Humanity Studies.

Parasuraman S. \& Simmers C.A. (2001). Type of employment, work-family conflict and well-being: A comparative study. Journal of Organizational Behaviour, 22 (5), 551-568.

Parasuraman, S. \& Greenhaus, J.H. (2002). Toward reducing some critical gaps in work-family research. Human Resource Management Review, 12, 299-312.

Poelmans, S. (2001).Work-Family Conflict as a mediator of the work stress-mental health relationship. Reseach paper 443

Powell, G. N. \& Greenhaus, J. H. (2006). Think piece: Is the opposite of positive negative? Career Development International, 11(7), 650-659.

Qureshi, M. I., Iftikhar, M., Abbas, S. G., Hassan, U., Khan, K., \& Zaman, K. (2013). Relationship between job stress, workload, environment and employees turnover intentions: What we know, what should we know. World Applied Sciences Journal, 23(6), 764-770.

really help balance work and family? Human Resource Management, 39 (1) 17-32

Ritter, K. J., Matthews, R. A., Ford, M. T., \& Henderson, A. A. (2016). Understanding role stressors and job satisfaction over time using adaptation theory. Journal of Applied Psychology, 101(12), 1655.

Robert J. B., Arjan V. R., \& Debbie M. T. (2010). Work-Family Conflict as a Cause for Turnover Intentions in the Hospitality Industry. Tourism and Hospitality Research.10,269-285.

Rothbard, N. P., Phillips, K.W., \& Dumans,T. L.(2005).Managing multiple roles: work-family policies and individuals' desires for segmentation. Organizational Science,16, 243-258

Rothbard, P. N. \& Dumas L. T. (2000).Work-Life Balance: A Psychological perspective.Hove and New York, Psychological press

Saunders, M., Lewis, P. \& Thornhill, A. (2007). Research methods for business students (4 ${ }^{\text {th }}$ ed.). Harlow: Prentice Hall.

Sert, A., Elçi, M., Uslu, T., \& Şener, İ. (2014). The effects of organizational justice and ethical climate on perceived work related stress. Procedia-Social and Behavioral Sciences, 150, 1187-1198.

Shahzad, K., Rehman, U., Shad, I., Gul A., \& Khan, A.M. (2011). Work-life policies and job stress as determinants of turnover intentions of customer service representatives in Pakistan. European Journal of Social Sciences, 19(3).403-405

Shang, S., O'Driscoll, M. P., \& Roche, M. (2016). Moderating Role of Acculturation in a Mediation Model of Work-Family Conflict among Chinese Immigrants in New Zealand. Stress and Health.

Shaw, R. D. (2014). The work-life balance of competitive marching band teachers: A multiple case study. Bulletin of the Council for Research in Music Education, (200), 63-80. 
INTERNATIONAL JOURNAL OF ACADEMIC RESEARCH IN BUSINESS AND SOCIAL SCIENCES

Vol. 8, No. 9, Sept. 2018, E-ISSN: 2222-6990 (C) 2018 HRMARS

Shuck, M.B. (2010). Employee engagement: An examination of antecedent and outcome variables. FIU Electronic Theses and Dissertations, Paper 235.

Spector, P. E. (2017). Puppet or puppeteer? The role of resource control in the occupational stress process. In Power, Politics, and Political Skill in Job Stress (pp. 137-158). Emerald Publishing Limited.

Stewart-Knox, B. J. (2014). Eating and stress at work: The need for public health promotion intervention and an opportunity for food product development?. Trends in Food Science \& Technology, 35(1), 52-60.

Waumsley, J.A. (2005). Work-life balance: A psychological perspective. Journal of Applied Psychology.92(6)1512-1523

Yang, N., Chen, C.C., Choi, J. \& Zou, Y. (2000). Sources of work-family conflict: A Sino-US comparison of the effect of work and family demands. Academy of Management Journal, 43, 113-123.

Oreg, S., Bartunek, J. M., Lee, G., \& Do, B. (2018). An affect-based model of recipients' responses to organizational change events. Academy of Management Review, 43(1), 65-86.

Sonnentag, S., \& Fritz, C. (2015). Recovery from job stress: The stressor-detachment model as an integrative framework. Journal of Organizational Behavior, 36(S1), S72-S103.

Mulki, J. P., \& Wilkinson, J. W. (2017). Customer-directed extra-role performance and emotional understanding: Effects on customer conflict, felt stress, job performance and turnover intentions. Australasian Marketing Journal (AMJ), 25(3), 206-214.

Slaughter, A. M. (2015). Why women still can't have it all (pp. 84-102). OneWorld.

Deery, M., \& Jago, L. (2015). Revisiting talent management, work-life balance and retention strategies. International Journal of Contemporary Hospitality Management, 27(3), 453472. 